\title{
Perbaikan Prasarana dan Penerapan Solar Sel di MI Miftahul Ulum
}

\author{
Murie Dwiyaniti' ${ }^{1}$ Ismujianto ${ }^{2}$, A.Damar Aji $^{3}$, Kusnadi ${ }^{4}$ \\ 1,2,3,4Program Studi Teknik Otomasi Listrik Industri, Jurusan Teknik Elektro, Politeknik Negeri Jakarta \\ *e-mail: murie.dwiyaniti@elektro.pnj.ac.id ${ }^{1}$, ismujianto@gmail.com² , adamaraji@gmail.com³ \\ kusnadi1957@gmail.com ${ }^{4}$
}

\begin{abstract}
MI Miftahul Ulum's infrastructure is very alarming to accept students, but the interest of the surrounding community to send their children to this school is quite large. It can be seen from the number of students who are stable every year. So we are trying to renovate the school infrastructure using the cooperation method in activities (1) repairing of a nearly collapsed terrace roof, (2) casting of a porch floor that has cracked due to the vibration of limestone mountain dredging equipment, (3) installation of solar cells as a source of electricity for terrace lighting and (4) training for teachers to introduce solar cells as an alternative source of electricity besides PLN. As a result, MI Miftahul Ulum's condition became better and brighter with the presence of solar cell-sourced terrace lamps.
\end{abstract}

Keywords: infrastruktur, MI Miftahul Ulum, renovation, solar cell

\begin{abstract}
Abstrak
Infrastruktur MI Miftahul Ulum sangat memprihatinkan untuk menerima siswa, tetapi minat masyarakat sekitar untuk menyekolahkan anak-anak mereka ke madrasah ini cukup besar. Hal ini terlihat dari jumlah siswa yang stabil setiap tahun. Sehingga kami berupaya untuk merenovasi infrastruktur sekolah dengan metode gotong royong dalam kegiatan (1) renovasi atap teras yang hampir runtuh, (2) pengecoran lantai teras yang telah retak karena getaran peralatan pengerukan gunung batu kapur,(3) pemasangan sel surya sebagai sumber listrik untuk penerangan teras dan (4) pelatihan kepada guru untuk memperkenalkan sel surya sebagai sumber listrik alternatif selain PLN. Hasilnya, kondisi MI Miftahul Ulum menjadi lebih baik dan lebih terang dengan adanya lampu teras bersumber solar sel.
\end{abstract}

Kata kunci: infrastruktur, MI Miftahul Ulum, renovasi, solar cell

\section{PENDAHULUAN}

Madrasah Ibtidaiyah Miftahul Ulum Desa Leuwikaret, Kecamatan Klapanunggal Kabupaten Bogor memiliki 6 kelas (kelas 1-6) dengan jumlah siswa tiap kelas antara 20-29, sehingga jumlah siswa keseluruhan adalah 149 siswa dari berbagai kalangan (Ulum, 2017). Ditinjau dari sarana dan prasarananya yang sangat minim, sekolah ini sebenarnya tidak layak menerima murid, tetapi animo masyarakat sekitar untuk menyekolahkan anaknya di madrasah ini cukup besar. Hal ini terlihat dari jumlah siswa yang stabil tiap tahun. Minimnya sarana dan prasana di madrasah ini karena keterbatasan dana Yayasan MI Miftahul Ulum. Sumber dana BOS tidak cukup untuk memenuhi operasional kegiatan belajar mengajar. Dukungan pemerintah daerah untuk membantu operasional sekolah sangat minim. Padahal sekolah ini berada tidak jauh dari kantor pusat Kabupaten Bogor.

Sekolah ini hanya memiliki 5 ruang kelas dengan kondisi sangat memprihatinkan, dimana hampir seluruh bagian bangunan mengalami kerusakan. Pemasangan instalasi penerangan tidak sesuai dengan Peraturan Umum Instalasi Listrik (PUIL) terkait dengan bahaya tegangan sentuh langsung maupun tidak langsung (Monice, 2019; B. S. Nasional, 2011). Selain itu ruang kelas terlalu sempit tidak sebanding dengan jumlah siswa dengan kondisi sebagian pintu ruang kelas rusak, lantai keramik pecah-pecah, atap bocor, plafon rusak, tembok kotor dan terkelupas, dan meja kursi banyak yang rusak. Kondisi ini belum sesuai standar minimal sarana dan prasarana sekolah yang ditetapkan oleh Menteri Pendidikan Nasional (P. M. P. Nasional, 2007).

Dengan kondisi tersebut, program studi Teknik Otomasi Listrik Industri (TOLI), Jurusan Teknik Elektro, Politeknik Negeri Jakarta berkoordinasi dengan mitra untuk menentukan 
prioritas perbaikan prasarana sekolah. Hasilnya adalah perbaikan atap dan lantai teras sebagai prioritas utama karena kondisinya cukup parah dan membahayakan siswa. Selain itu, atap teras yang diperbaiki ditambahkan solar sel untuk menyediakan sumber listrik bagi penerangan teras sekolah. Upaya ini dilakukan agar suasana sekolah menjadi terang tanpa memberatkan biaya listrik sekolah. Kegiatan ini juga bisa membuka wawasan guru dan siswa tentang pemanfaatan energy terbarukan khususnya tenaga matahari sebagai sumber listrik selain PLN. Siswa usia sekolah dasar lebih mudah memahami pengetahuan baru dengan menggunakan bentuk atau penerapan langsung (Mumtahanah, 2014). Sehingga solar sel yang dipasang pada kegiatan ini dapat dijadikan pembelajaran nyata bahwa tenaga matahari dapat diubah menjadi listrik.

Secara tidak langsung kegiatan ini merupakan program aksi pengembangan kemampuan masyarakat, yaitu memberikan pengetahuan tentang sumber energi terbarukan dan penerapannya pada penerangan sekolah. Kegiatan ini juga dimaksudkan untuk membuka wacana bagi Pemda setempat, dalam hal ini diwakili oleh Kecamatan Klapanunggal, tentang penerapan solar sel sebagai sumber listrik sehingga masyarakat tidak bergantung pada PLN untuk sumber listriknya.

\section{METODE}

Kegiatan pengabdian masyarakat telah dilaksanakan di MI Miftahul Ulum yang berlokasi di Kp. Guha Kulon Rt.01/01 Desa Leuwikaret, Klapanunggal, Bogor. Waktu pelaksanaan bertahap dimulai pada bulan Juli sampai September 2019. Khalayak sasaran kegiatan adalah infrastruktur sekolah dan guru. Guru MI Mitahul Ulum, dosen PNJ, dan mahasiswa PNJ terlibat langsung dalam setiap kegiatan mulai dari pembangunan sampai pelatihan.

Metode pengabdian masyarakat ini adalah bergotong royong memperbaiki atap dan lantai teras, menerapkan solar sel dan instalasi lampu, serta transfer knowledge ke guru tentang pemanfaatan solar sel. Pelaksanaan kegiatan ini dibagi dalam beberapa tahap, yaitu:

1. Tahap renovasi atap teras sekolah. Atap teras sekolah sudah rusak sehingga perlu direnovasi agar tidak runtuh dan membahayakan siswa.

2. Tahap renovasi lantai teras sekolah. Keramik pada teras sekolah sudah retak-retak akibat getaran alat pengeruk gunung kapur. Sehingga perlu diperbaiki agar siswa tidak tersandung retakkan keramik.

3. Tahap pembangunan sistem kelistrikan energi baru dan terbarukan untuk sumber listrik penerangan lampu teras sekolah yang meliputi:

a Merancang tata letak dan kebutuhan daya listrik solar sel;

b Membuat panel oudoor untuk sistem solar sel;

c Menghubungkan atau menginstalasi beban-beban listrik ke panel solar sel;

4. Tahap transfer knowledge berupa pelatihan tentang energi terbarukan yang berasal dari energi matahari (solar sel).

Evaluasi kegiatan pengabdian masyarakat dilakukan secara bertahap. Tujuannya untuk mengukur ketercapaian kegiatan dengan cara mengecek jadwal dan kesesuaian pekerjaan yang telah diselesaikan. Indikator keberhasilan dari kegiatan ini adalah:

1. Terselesaikannya semua perbaikan atap dan lantai teras, pemasangan solar sel, panel, dan instalasi penerangan teras;

2. Terlaksananya kegiatan transfer knowledge ke guru tentang pemanfaatan solar sel sebagai alternatif energi listrik.

\section{HASIL DAN PEMBAHASAN}

Dalam upaya menjadikan MI Miftahul Ulum sebagai sekolah yang layak bagi siswa, kegiatan pengabdian masyarakat telah dilaksanakan oleh civitas akademika PS TOLI berupa 
renovasi atap dan teras sekolah, pemasangan solar sel dan lampu teras, serta pelatihan untuk guru terkait dengan pemanfaatan solar sel.

\section{A. Renovasi atap teras}

Atap teras existing berukuran 8 x 5 meter sebagian besar dimakan rayap dan bocor sehingga perlu melakukan renovasi. Semua kayu asbes dan plafon diganti baru. Kegiatan renovasi atap teras dapat dilihat pada Gambar 1.
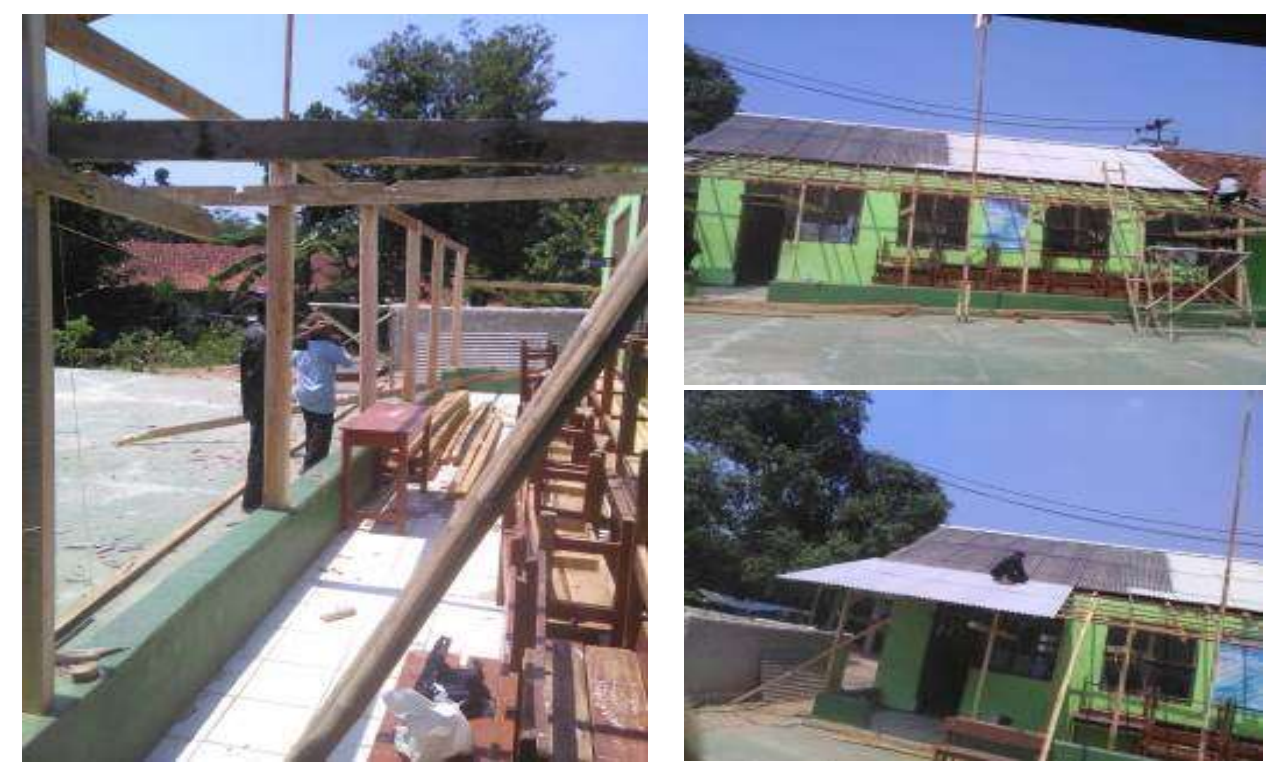

Gambar 1. Kegiatan renovasi atap teras sekolah

\section{B. Renovasi lantai teras}

Lokasi MI Miftahul Ulum berada pada ring 1 industri semen, sehingga getaran alat pengeruk dan pengebor gunung kapur yang merupakan bahan utama pembuat semen sangat terasa. Akibat dari getaran ini hampir semua keramik lantai pecah. Hal ini sangat membahayakan siswa. Pecahan keramik dapat membuat siswa tersandung dan jatuh. Selain itu, lantai keramik yang pecah sangat tidak enak dipandang. Oleh karena itu, renovasi juga dilakukan pada lantai teras sekolah dengan ukuran 8 × 2 meter. Semua keramik dilepas dan lantai tersebut di cor lalu di cat dengan menggunakan cat lapangan. Pengecoran lantai tanpa pemasangan keramik kembali karena coran lebih kuat terhadap getaran. Kegiatan renovasi lantai teras terlihat pada Gambar 2.
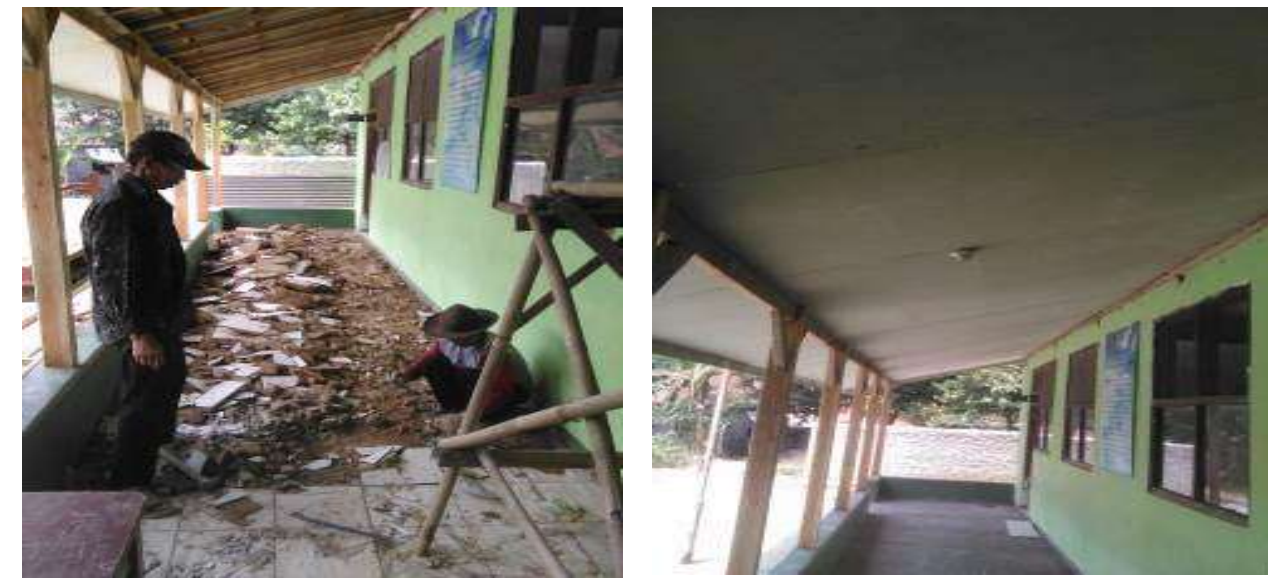

Gambar 2. Renovasi lantai teras 
C. Pembangunan sistem kelistrikan DC tenaga surya

Sistem kelistrikan DC dibangun dengan memanfaatkan tenaga surya yang sangat berlimpah. Tujuan penggunaan sistem DC tenaga surya ini adalah agar tidak membebani biaya listrik sekolah. Beban listrik yang akan digunakan adalah lampu teras. Perhitungan beban dan kebutuhan solar sel (Bachtiar, 2006; Dwiyaniti, Riandini, \& Supriyono, 2020), sebagai berikut:

1. Perhitungan beban listrik:

Lampu 8 buah x 4,5 Watt x 10 jam (menyala) = 360 Watt

2. Perhitungan jumlah solar sel yang dibutuhkan:

Jumlah solah panel = total daily Watt : charging efektif

$$
=360 \text { watt }: 5 \mathrm{Jam}=72 \text { Watt Peak (WP) }
$$

Jadi solar sel yang digunakan adalah 80 WP sebanyak 1 pcs.

3. Perhitungan jumlah baterai yang diperlukan:

Baterai yang digunakan adalah $12 \mathrm{v}, 70 \mathrm{Ah}$, dengan cadangan selama 3 hari.

Jumlah baterai $=(360$ watt $/$ day x 2 hari $):(12 \mathrm{~V} \times 70 \mathrm{Ah})=0,8$ pcs dibulatkan 1 pcs.

Jadi baterai yang digunakan sebanyak 1 pcs, baterai $12 \mathrm{~V}, 70 \mathrm{Ah}$

Panel solar sel yang digunakan pada kegiatan ini berbahan monocristallin karena lebih efesien menangkap panas matahari (Dzulfikar \& Broto, 2016; Quansah \& Adaramola, 2018; Zaini et al., 2015). Sehingga proses pengisian baterai menjadi lebih optimum. Sedangkan baterai charge controller (BCR) menerapkan teknologi Pulse width modulation (PWM) untuk mengatur fungsi pengisian baterai dan pembebasan arus dari baterai ke beban. Panel solar 12 Volt umumnya memiliki tegangan output 16-21 Volt, jadi tanpa BCR, baterai akan rusak oleh over-charging dan ketidakstabilan tegangan (Heri, 2012). Proses pemasangan solar sel dilaksanakan secara bertahap dimulai dari pemasangan panel, solar sel, BCR, dan baterai (Hakim, 2017). Kegiatan pemasangan solar sel terlihat pada Gambar 3.
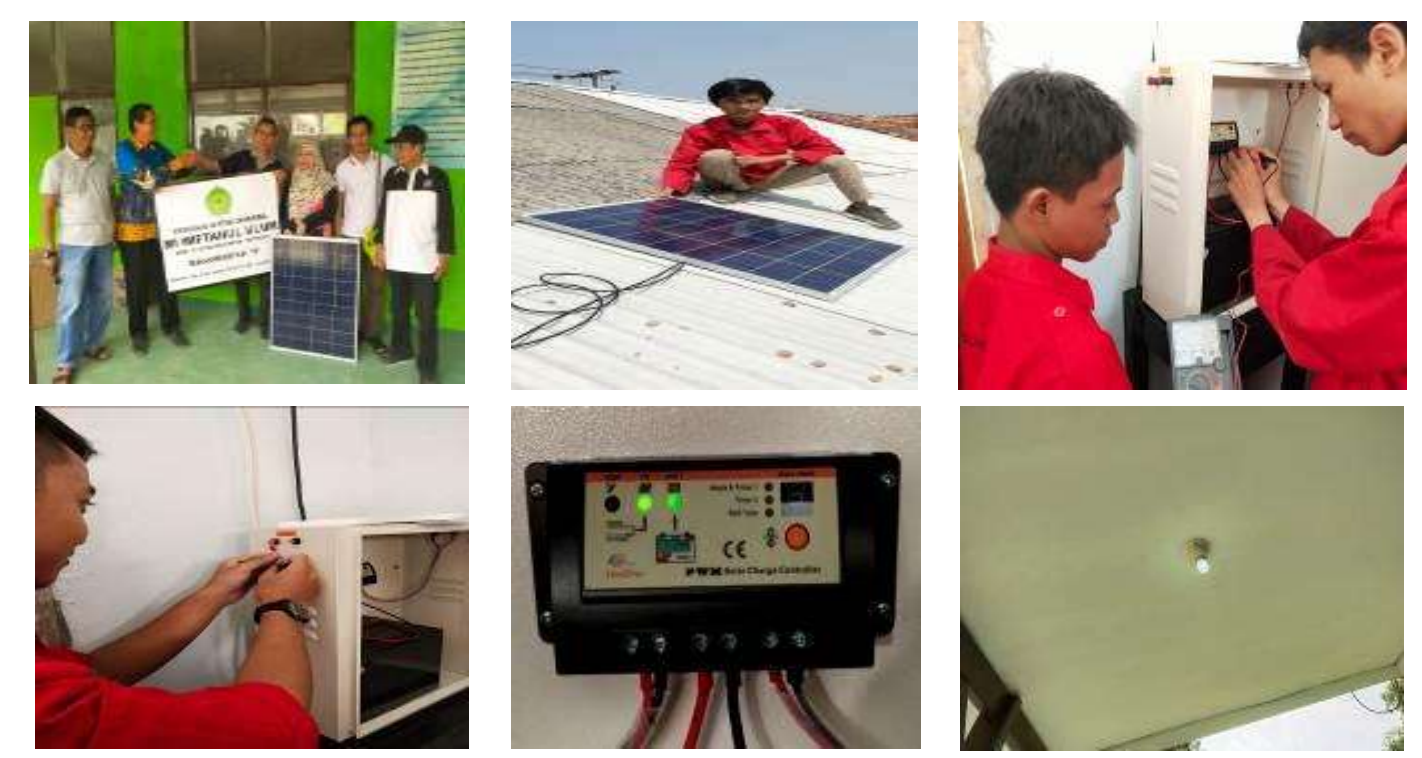

Gambar 3. Kegiatan penyerahan, pemasangan dan instalasi solar sel

Instalasi lampu penerangan teras sekolah dipasang sesuai dengan gambar instalasi. Setelah proses pembangunan sistem kelistrikan DC selesai, dilakukan pengujian dengan hasil seperti pada Tabel 1. 
Tabel 1. Hasil pengukuran sistem kelistrikan DC

\begin{tabular}{lccc}
\hline \multicolumn{1}{c}{ Beban } & Tegangan $(\mathrm{V})$ & Arus $(\mathrm{A})$ & Suhu $(0 \mathrm{C})$ \\
\hline Tanpa beban & 12 & 0 & 25 \\
Lampu & 12 & 0,75 & 25 \\
\hline
\end{tabular}

\section{Pelatihan}

Pelatihan dilaksanakan satu hari dengan peserta guru-guru MI Miftahul Ulum. Tujuan pelatihan ini adalah menjelaskan kepada guru-guru tentang sistem kelistrikan DC yang bersumber dari energi matahari. Penjelasan meliputi bagaimana proses energi matahari menjadi energi listrik, komponen-komponen yang terpasang, instalasi listrik dan cara menginstalasinya, serta perawatannya. Kegiatan pelatihan dapat dilihat pada Gambar 4.
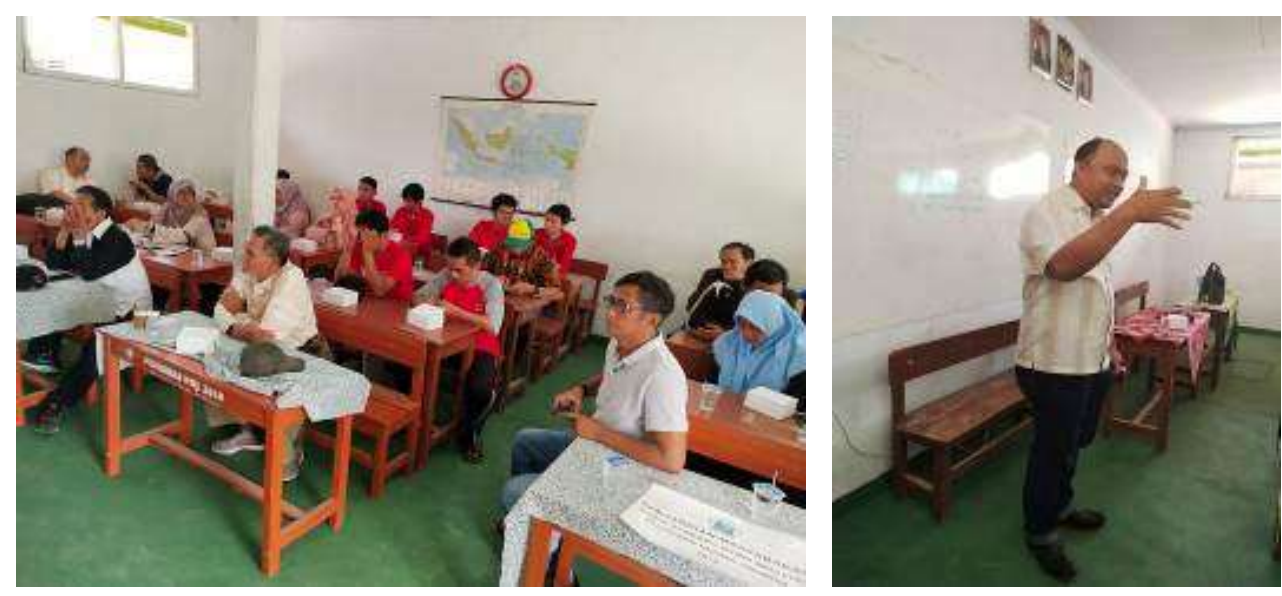

Gambar 4. Kegiatan pelatihan untuk guru MI Miftahul Ulum

\section{E. Keberhasilan Kegiatan}

Serangkaian kegiatan pengabdian masyarakat telah dilaksanakan dengan baik dan sesuai dengan rencana. Keberhasilan kegiatan ini dapat terlihat dari makin cantiknya sekolah MI Miftahul Ulum. Prasarana atap dan lantai teras menjadi lebih nyaman sehingga siswa bisa melakukan aktifitas di teras tanpa kuatir tertimpa atap. Lampu DC untuk penerangan telah terinstalasi dan menyala sesuai dengan kebutuhan. Guru-guru telah mempunyai pengetahuan tentang sistem kelistrikan DC dari sumber energi matahari. Harapannya, guru-guru ini dapat mentransfer pengetahuan yang diperoleh kepada siswa sehingga terbentuk paradigma baru bahwa sumber listrik tidak harus dari PLN namun bisa diupayakan menggunakan energi matahari. Tim pengabdian masyarakat dosen dan mahasiswa terlihat pada Gambar 5.
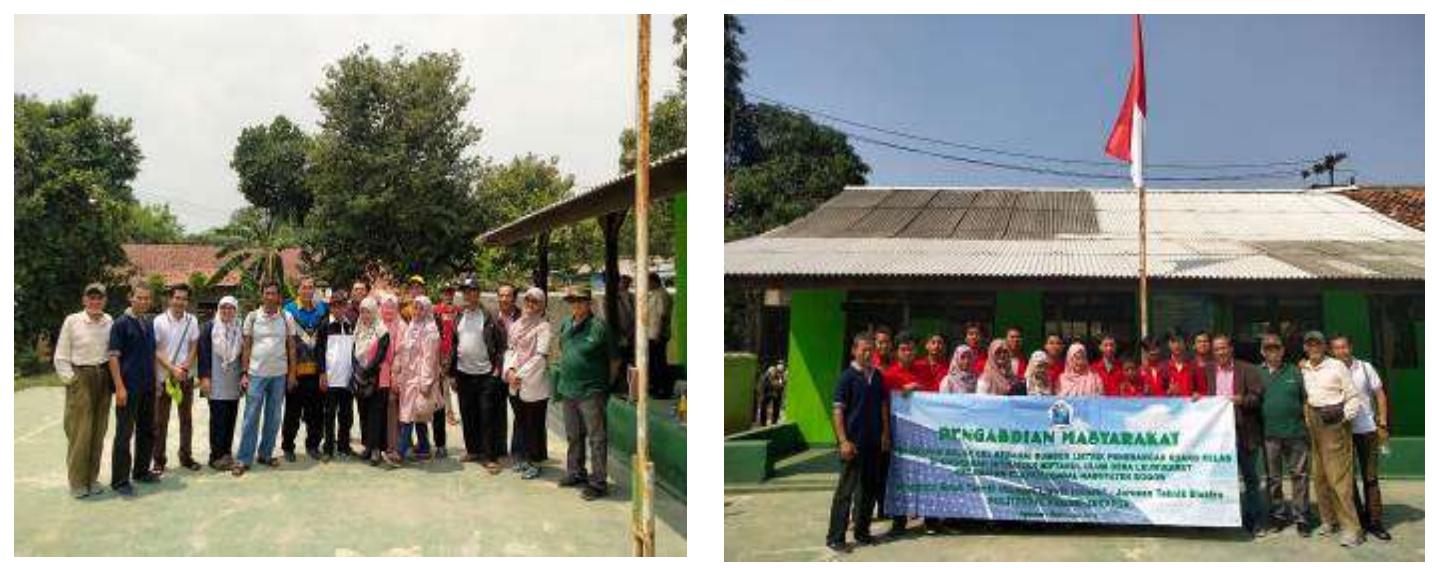

Gambar 5. Tim pengabdian masyarakat berbasis prodi Teknik Otomasi Listrik Industri 


\section{KESIMPULAN}

Perbaikan prasarana atap dan lantai teras serta penerapan solar sel sebagai sumber listrik penerangan sekolah telah dilaksanakan dengan baik. Keberhasilan kegiatan ini terlihat pada tampilan sekolah MI Miftahul Ulum yang semakin rapih. Lampu penerangan teras menyala dengan baik sehingga suasana sekolah pada malam hari menjadi terang benderang.

\section{UCAPAN TERIMA KASIH}

Penulis mengucapkan terima kasih kepada P3M Politeknik Negeri Jakarta yang telah memberikan dukungan financial kegiatan ini melalui skema Pengabdian Masyarakat berbasis Prodi.

\section{DAFTAR PUSTAKA}

Bachtiar, M. (2006). Prosedur perancangan sistem pembangkit listrik tenaga surya untuk perumahan (solar home system). SMARTek, 4(3).

Dwiyaniti, M., Riandini, R., \& Supriyono, E. (2020). Pemanfaatan Solar Sel dan Budidaya Perikanan sebagai Upaya Menuju Kemandirian Finansial di Sekolah Kami. Panrita Abdi-Jurnal Pengabdian pada Masyarakat, 4(2), 146-154.

Dzulfikar, D., \& Broto, W. (2016). Optimalisasi Pemanfaatan Energi Listrik Tenaga Surya Skala Rumah Tangga. Paper presented at the Prosiding Seminar Nasional Fisika (E-Journal).

Hakim, M. F. (2017). Perancangan Rooftop Off Grid Solar Panel Pada Rumah Tinggal Sebagai Alternatif Sumber Energi Listrik. DINAMIKA DOTCOM, 8(1).

Heri, J. (2012). Pengujian Sistem Pembangkit Listrik Tenaga Surya Solar Cell Kapasitas 50wp. Engineering, 4(1).

Monice, P. (2019). Sosialisasi Hemat Energi dan Bahaya listrik di Posyandu Lancang Kuning RT 04 RW 15 KecamatanTampan. Dinamisia: Jurnal Pengabdian Kepada Masyarakat, 3(1), 50-52.

Mumtahanah, N. (2014). Penggunaan Media Visual dalam Pembelajaran PAI. Al Hikmah: Jurnal Studi Keislaman, 4(1), 7-7.

Nasional, B. S. (2011). Persyaratan Umum Instalasi Listrik 2011 (PUIL 2011). Jakarta: BSN.

Nasional, P. M. P. (2007). Peraturan Menteri Pendidikan Nasional Republik Indonesia Nomor 24 Tahun 2007 Tentang Standar Sarana Dan Prasarana Untuk Sekolah Dasar/Madrasah Ibtidaiyah (SD/MI), Sekolah Menengah Pertama/Madrasah Tsanawiyah (SMP/MTS), dan Sekolah Menengah Atas/MadrasahAliyah (SMA/MA). Jakarta: Menteri Pendidikan Nasional.

Quansah, D. A., \& Adaramola, M. S. (2018). Comparative study of performance degradation in polyand mono-crystalline-Si solar PV modules deployed in different applications. International Journal of Hydrogen Energy, 43(6), 3092-3109.

Ulum, M. (2017). Database Siswa Miftahul Ulum.

Zaini, N., Ab Kadir, M., Izadi, M., Ahmad, N., Radzi, M., \& Azis, N. (2015). The effect of temperature on a mono-crystalline solar PV panel. Paper presented at the 2015 IEEE Conference on Energy Conversion (CENCON). 